\title{
On the Emergence of Living Systems
}

\author{
Bruce H. Weber
}

Received: 2 July 2009 / Accepted: 14 July 2009 /

Published online: 9 October 2009

(C) Springer Science + Business Media B.V. 2009

\begin{abstract}
If the problem of the origin of life is conceptualized as a process of emergence of biochemistry from proto-biochemistry, which in turn emerged from the organic chemistry and geochemistry of primitive earth, then the resources of the new sciences of complex systems dynamics can provide a more robust conceptual framework within which to explore the possible pathways of chemical complexification leading to living systems and biosemiosis. In such a view the emergence of life, and concomitantly of natural selection and biosemiosis, is the result of deep natural laws (the outlines of which we are only beginning to perceive) and reflects a degree of holism in those systems that led to life. Further, such an approach may lead to the development of a more general theory of biology and of natural organization, one informed by semiotic concepts.
\end{abstract}

Keywords Biogenesis $\cdot$ Biosemiosis $\cdot$ Complexity $\cdot$ Emergence . Natural organization · Origin of life

\section{Introduction}

The origin of life is increasingly viewed as the result of a natural process of emergence rather than an event of creation or a line to be crossed on a phase diagram (R.F. Fox 1997; Weber 1998, 2007; Kauffman 2000; Lurquin 2003; Lal 2008). If the

B. H. Weber (凶)

Biochemistry, California State University Fullerton, Fullerton, CA 92835-3142, USA

e-mail: bhweber@fullerton.edu 
origin of life is a highly improbable event, it can either be due to chance or seem to be a miracle brought into being by a cause outside of nature. The latter is the claim of creationists and advocates of intelligent design (Meyer 2009). Specifically they challenge any attempt to account for the emergence of life by natural causes and processes. In contrast, the methodological naturalism of scientists assumes that scientific explanations must be confined to causes within nature. This provides a framework for exploring the possible avenues by which life might have arisen as an expected result of the action of natural processes. In what follows I will review the history of ideas about the origin of life and assess the current status of such research, particularly in light of the new sciences of emergent complexity and biosemiotics.

\section{Early Scientific Speculation on the Origin of Life}

Darwin was careful to bracket off the issue of the origin of life from his account of the origin of species through the action of natural selection culling heritable variations in populations of species in particular environments. He stated, "How a nerve becomes sensitive to light hardly concerns us more than how life itself originated" (Darwin 1859, 187), and envisioned life being "breathed into a few forms or into one" (Darwin 1859, 490). Privately, however, Darwin was willing to speculate in more naturalistic terms. In a letter to Joseph Hooker in 1871 he wrote, "But if (and oh what a big if) we could conceive in some warm little pond with all sorts of ammonia and phosphoric salts, light, heat, electricity and etc., present, that a protein compound was chemically formed, ready to undergo still more complex changes" (Cambridge University Library Manuscript Collection: DAR 94, 188-189). One reason for keeping his speculations private was that there was a ongoing debate in the nineteenth century about the spontaneous generation of life based upon the "active materialism" of French biologists, such as Lamarck and Geoffroy. This view, introduced into England in the 1820s by Robert Grant, one of Darwin's teachers, saw matter as capable of spontaneous self-organization. This was a position accepted and avidly advocated by English socialists of the 1830s (Desmond 1989; Fry 2000; Strick 2000). In the end it was shown that spontaneous generation was an illusion and that even if such incipient life should form today it would be quickly devoured by existing life forms. It was Herbert Spencer argued that biological evolution was part of a cosmic process of becoming more inhomogeneous and complex in which the origin of life was an instance (Spencer 1864). At the beginning of the last century Josiah Royce clearly distinguished the broader vision of Spencerism from the more focused claims of Darwinism (Royce 1904). Most advocates of the Modern Evolutionary Synthesis, or neo-Darwinism, continue to argue that evolutionary theory and the origin of life are conceptually separate issues (Scott 2004). Opponents of Darwinism continue to conflate the two (Behe 1996; Dembski 1998; Meyer 2003, 2009; Bradley 2004).

The possibility of an abiotic generation of living entities, under the conditions of the primitive earth, was taken up anew in the 1920s and 1930s by scientists, many of whom as it happened had Marxist philosophical commitments. At this time the understanding of biochemistry and geochemistry had advanced sufficiently that scientifically based speculations about a natural origin of life seemed possible. J.B.S. 
Haldane and Alexander Oparin suggested that abiotic chemical processes could produce and accumulate organic compounds of increasing complexity from which a possible proto-metabolism of chemical transformations similar to the metabolism in modern cells could emerge (Haldane 1929; Oparin 1924, 1938). Another Marxist scientist, J.D. Bernal suggested that various clays could provide the catalytic and template characteristics needed to facilitate the emergence of such a protometabolism (Bernal 1951, 1967). Such speculations set the stage for experimental and theoretical exploration of the possible routes of the emergence of life over the next 60 some years.

\section{3 and After but Before the Rise of Complexity Theories}

The year 1953 is remarkable in the history of science not only for the discovery of the double helical structure of DNA (Watson and Crick 1953) but also for the demonstration, by then graduate student Stanley Miller working in the laboratory of Harold Urey at the University of Chicago, that chemical processes possible on the early earth could produce molecules needed for life (Miller 1953). His experiment showed that an electrical discharge passed through a mixture of gases of methane, ammonia, water and hydrogen (then believed to reproduce the earth's primitive atmosphere) produced a mixture of some of the amino acids needed as building blocks for proteins. This set off a flurry of activity to see how many different amino acids could be made as well as other key molecules needed for life, such as sugars and the purine and pyrimidine bases needed for nucleic acids (see Lahav 1999; Wills and Bada 2000; Bada and Lazcano 2003 for a description of the Miller experiment and its subsequent impact).

After 1953 it became commonplace to think of a pre-biotic "soup" or "broth" of increasingly complex molecules from which macromolecular polymers, proteins and nucleic acids, could be formed (R.F. Fox 1997; Lurquin 2003). This soup scenario contrasted with the earlier metabolism-first proposals of Oparin, Haldane, and Bernal that saw directed synthesis of protein catalysts from nucleic acid templates as arising later in the emergence of life after the a metabolic web of chemical transformations had arisen. The "soup" model proposed instead the following sequence:

Small molecules $\rightarrow$ macromolecules $\rightarrow$ directed synthetic systems $\rightarrow$ protocell $\rightarrow$ cell

where with the appearance of macromolecules capable of self-replication (nucleic acids) arose by accident. Afterwards the macromolecular catalysts (proteins acting as enzymes) would have made metabolism possible. This latter approach has dominated recent research on the emergence of life. In one version it is assumed that proteins came first and later became templated by nucleic acids S.W. Fox and Dose 1972; S.W. Fox 1988). In another, known as the "RNA world" it is assumed that nucleic acids, specifically RNA, came first and had both catalytic and template function (Woese 1967; Orgel 1968; Cech 1986). Alternatively, it is possible that both types of polymers (proteins and RNA) emerged together through mutual chemical interactions (R.F. Fox 1982, 1988, 1997; Wicken 1987). More recently, there have been various attempts to revive versions of metabolism first (Morowitz 1992; 
Wächterhäuser 1988a, b, 1992, 1997). Finally, there are proposals to place some sort of encapsulating barrier, which would allow protocell formation, as the first crucial step in the process of the emergence of life (Morowitz et al. 1991; Morowitz 1992). In effect, each approach assumes priority to some aspect characteristic of living systems today. There is also the possibility that the emergence might have involved parallel processes of several or all of these features (Weber 1998, 2000, 2007).

Importantly, the Miller-Urey experiment, as it is known, moved thinking about the origin of life from primarily philosophical assumptions and theoretical speculations about how biochemical systems came into being to an empirical research program. Sidney Fox demonstrated that at high temperatures (around $200^{\circ} \mathrm{C}$ ) amino acids could polymerize to form proteins (S.W Fox 1965). This suggested that proteins were the first macromolecules to emerge from the soup and, since today proteins function mainly to catalyze metabolic chemical reactions, the proteinoid spheres could have been the cradle in which life emerged. It is possible that such proteinoids might have formed at lower temperatures (Kumar and Oliver 2002; Leman et al. 2004). It has also been suggested that hydrogen cyanide polymers, which also form in the Miller-Urey experiment, could yield polypeptides (and possibly even polynucleotides) directly when reacted with water (Matthews and Moser 1967; Liebman et al. 1995; Minard et al. 1998).

Nearly concurrently it was shown that the important purine adenine could be produced abiotically from hydrogen cyanide (Oró 1961). As other components of nucleic acids appeared to be easily produced abiotically it was suggested that ribonucleic acid (RNA) might have been the original macromolecule since it could not only serve as a template for its own replication but had the potential for some limited catalytic activity (Woese 1967; Orgel 1968). Various ideas have been explored by which polymers of nucleotides could have formed. When catalytic activity of present-day RNA was demonstrated (Cech 1986, 1987; Wilson and Szostak 1995) such proposals became more credible and led to the proposal of an "RNA world" in which RNA was the first template, replicator and catalyst (Orgel 1992; Joyce and Orgel 1993; Gesteland and Atkins 1993; Wilson and Lilley 2009). This fit well with Richard Dawkins's notion that life arose as a highly improbable event with the first replicating nucleic acids that subsequently decorated themselves with proteins, lipids, carbohydrates, and cellular structure to protect and better perpetuate themselves by templating such "gene machines" (Dawkins 1976, 1989).

There are problems with such RNA-first scenarios. Until recently no convincing chemical route had been proposed by which the purine and pyrimidine bases might be attached to ribose abiotically, but a recent report suggest that in a plausible abiotic, complex-chemical-systems environment such syntheses could have been achieved (Joyce and Orgel 1993; Schwartz 1997; Szostak 2009; Powner et al. 2009). Even so, although RNA can do some limited catalysis, it lacks the range of catalytic activity possible with a set of polypeptides. Stuart Kauffman has explored the potential of ensembles of randomly generated catalytic peptides to foster a wide range of chemical reactions, what he terms 'catalytic task space' (Kauffman 1993). Kauffman's computer simulations show that the great richness of possible sequences of the polypeptide chains of proteins (protein sequence space) easily cover the possible tens of million possible chemical reactions of catalytic task space. Such 
auto-catalytic sets of polypeptides not only catalyze reactions generally but also specifically reactions that led to the formation of more of the compounds of the reaction set, including catalysts (hence 'auto-catalytic'). When an ensemble of autocatalytic sets of polymers catalyzes all of the reactions necessary to sustain itself, the condition of 'catalytic closure' obtains and the ensemble behaves to sustain itself, even reproduce itself after a fashion. In such autocatalytic sets the catalysis of purine and pyrimidine attachment to ribose would be easily feasible and thus RNA could be synthesized by several plausible routes (Weber 1998, 2000, 2007; Powner et al. 2009). Both proteins and nucleic acids could interact to mutually stabilize each other and through such interactions that could have led to specific templating and ultimately gave rise to the genetic code in which the analog code of proteinfunction is specified by the digital code of DNA and RNA (Carter and Kraut 1974; Wicken 1987; Weber 1998; Hoffmeyer 2009). Further, Kauffman's protein catalyzed protometabolism suggests the possibility that the templating information of nucleic acids arose to stabilize information in digital coding about those analog protein sequences that were more chemically and thermodynamically efficient in supporting the autocatalytic sets.

Not only is catalytic closure important, but also is physical closure. All cells have a membrane barrier of phospholipids that encapsulates them, providing an osmotic barrier for molecules and ions, as well as defining self from not-self and environment. This prevents diffusion of ions and small organic molecules across the barrier because the lipids have amphiphilic character. An amphiphilic molecule has a hydrophobic ("water hating") end and a hydrophilic ("water loving") end. These molecules spontaneously arrange in water to create vesicles of bilayers with a hydrophobic barrier to the movement of charged molecules and atoms while separating an inside from the rest of the outside aqueous environment. If such vesicles could have arisen early in the process of the emergence of life, they could have countered the problems of dilution and diffusion that would otherwise plague the development of autocatalytic sets. So a protocell first model has been proposed (Morowitz et al. 1991; Morowitz 1992; Deamer et al. 2002). Amphiphilic molecules, though not lipids, have been discovered in carbonaceous chondrites (meteors containing carbon compounds) and shown capable of producing bilayered vesicles (Deamer and Pashley 1989; Deamer et al. 2002). Amphiphiles of terrestrial origin, likely to have been available early in the history of the earth, have also been show to form vesicles (Ourisson and Nakatani 1994). Such amphiphiles show autocatalytic self-replication (Bachmann et al. 1992; Luisi 2006).

Further, the existence of some type of membrane would have allowed for energy capture mechanisms that could have powered the chemistry of self-organization. Only when systems are driven away from chemical and thermodynamic equilibrium can internal structures in the system arise (Prigogine 1962, 1980, 1997; Prigogine and Stengers 1984; Wicken 1987; Depew and Weber 1995; Weber and Depew 1996; Kauffman 2000; Kleidon and Lorenz 2005). All types of cells use energy (chemical, osmotic, photochemical) to pump protons across membranes to produce a difference in proton concentration and charge across the membranes. This difference can then be used to do chemical or osmotic work; the mechanisms of such systems are called 'chemiosmotic' (Mitchell 1961). The aqueous environment places chemical constraints on, as well as provides opportunities for, the types of compounds and 
their reactions that are essential for living systems found on earth (Williams and Fraústo da Silva 1996, 1999, 2003, 2006, 2008). Phosphoanhydrides, such as polyphosphates initially and subsequently in life today ATP, are especially suited for serving as the "energy currency" of cells at neutral $\mathrm{pH}$ because of their unique combination of properties of kinetic stability and thermodynamic instability in water (Westheimer 1987; Baltscheffsky and Baltscheffsky 1992; Arhenius et al. 1997; Yamagata and Inomata 1997). Indeed, the interplay of hydrophobic and hydrophilic domains of membranes provides the basis for the synthesis of ATP and more generally for biological energetics (Mitchell 1961; Williams 1961; Prebble and Weber 2003; Weber and Prebble 2006). Thus, it can be expected that very early in the emergence of life that chemiosmotic mechanisms arose. This is substantiated by the observation that the two characteristics that are virtually universal, hence present in the last common ancestor of all life, are the genetic code and chemiosmotic energy coupling (Lane 2006). Also, polypeptides embedded in such membranes could also be involved in responding to changes in concentration of certain molecules in the environment and could be the starting point for "interpretation" of such "signals" in the environment and possibly trigger a response within the proto-cell that could be construed as the beginning of emergence of agency (Kauffman 2000, 2004).

The observation that amphiphilic vesicles derived from meteorites, when supplemented with polycyclic hydrocarbons also from meteorites, pump protons when exposed to light, suggests that a proto-cell first scenario could provide energy as well as a container for the chemistry of emergence (Deamer 1992; Weber 1998, 2000). But, this is not the only way that compartmentalization and chemiosmotic processes could have arisen. Iron-sulfur membranes have been produced under conditions thought to have existed in the primitive oceans of early earth (Martin and Russell 2003). Hot, reduced alkaline waters produced by thermal vents in the crust could have swept up from the ocean depths to mix with cooler, more oxidized, and acidic waters containing iron-sulfur salts and carbon dioxide from above. Where these waters mixed microscopic bubbles with membranous structures would have formed (these form in the laboratory and there is evidence that such structures have formed in the past in nature). The outside of these iron-sulfur membrane vesicles were naturally acidic and the interior basic, creating a chemiosmotic proton gradient, which in turn could drive polyphosphate synthesis. Further, the iron-sulfur membrane would have all the catalytic and chemical potential for oxidationreduction reactions that has been proposed (Wächterhäuser 1988a, b, 1992, 1997). Such an iron-sulfur membrane would have allowed simultaneously for a catalytic surface, chemiosmotic mechanisms, and containment of molecules against diffusion. Such might have been the cradle of life. There are plausible routes by which amino acids and purines and pyrimidines, and their polymers, could have been synthesized from the hydrogen, ammonia, hydrogen cyanide, hydrogen sulfide, methane, and formic acid believed to be produced by the geochemistry of the thermal vents (Imai et al. 1999; Leman et al. 2004). From the geochemistry the beginnings of a protometabolism could have emerged, ultimately producing catalytic closure and a metabolism capable of generating the lipid molecules that came to replace the ironsulfur membrane. While such iron-sulfur membranes could have provided a stable chemical environment over hundreds of millions of years, the ability to generate lipids and form cellular membranes meant that cells could break free from this 
interface zone and occupy a wide range of niches. This would have been so advantageous that there would be no looking back, however, proteins containing iron-sulfur reaction centers remain in the lipid-membrane-embedded respiratory chains of all cells as a relic of this past history. Probably by about 3.8 to 3.5 billion years ago the eubacteria and the archaea (or archaebacteria), two of the three main branches of life, would have been free to "roam" and to explore new niches in which to flourish. Much later (around 2.0 to 2.5 billion years ago), a symbiotic association of a bacterium and an archaebacterium led to the emergence of complex cells known as eukaryotes by a process that seems much more highly contingent than the paths that led to unicellular bacterial and archebacterial life (Martin and Russell 2003; Lane 2006). The eukaryotes were much more efficient in their ability to capture metabolic energy from nutrients and thus were able to sustain not only greater internal complexity but also to form stable multicellular organisms over the past 800 million years or so (Lane 2006).

\section{Assessing the Status of Origin of Life Research}

Ronald Fox in his review provided the background of basic chemistry that underpins research on the origin of life, particularly that generating the "building blocks" of proteins and nucleic acids (R. Fox 1997). In the same year a special issue of the Journal of Theoretical Biology was devoted to the origin of life. One fundamental conclusion was that if we can understand the chemistry underlying the emergence of life, then we can know how likely life is to exist elsewhere in the universe. This conclusion still holds up today. Jeffrey Bada evaluated the status of research on how life began on earth in 2004 by concluding that anywhere water and organic polymers, such as proteins and nucleic acids, can arise there likely will also be living entities (Bada 2004). Steven Benner has suggested that what is essential is a solvent system, availability of elements, such as carbon, hydrogen, nitrogen, sulfur, and oxygen, and a thermodynamic disequilibrium at temperatures consistent with chemical bonding (Benner et al. 2004). Although this general notion seems likely, there are many details still to be worked out.

One aspect of the problem of understanding how life emerged on earth, or might emerge elsewhere, is that it seems likely to have been a process of emergence rather than an event or even a sequence of discrete events. As seen above, there are plausible scenarios in which metabolism is first, or proteins, or nucleic acids, or amphiphilic membranes. Or possibly aspects of all of these needed to be present in crude and inchoate form before the interaction of self-organization and selection might have acted to effect the transition from chemical complexity to biological chemistry (Depew and Weber 1995; Weber and Depew 1996, Weber 1998, 2000).

Ideas about what conditions obtained on the primitive earth change as more is learned about geochemistry, such that the conditions assumed by Miller and Urey seem unlikely to have been the general case, although there might well have been local environments (near volcanoes or deep-ocean hydrothermal vents) where the chemical environment was as reducing as they assumed (see Schopf 1983 and particularly Bada 2004 for a discussion of the chemistry of the early earth and its implications for the Miller-Urey experiment). Alternative routes involving carbon 
monoxide could also produce amino acids and, further, the formation and polymerization of hydrogen cyanide provide major chemical pathways to amino acids and the purine and pyrimidine constituents of nucleic acids (Bada 2004).

It must be remembered that any earlier entities that existed during the process of emergence of life would have been either out-competed and gone extinct or used as a nutrient source by cells that we would recognize as being alive. In the five decades since the Miller-Urey experiment we have come to understand much more about geochemistry as well as biochemistry, but we are still very much early in the research program to understand how life emerged here on earth and how it might emerge elsewhere, a point made recently by Michael Ruse (Ruse 2006). We can well expect in the decades to come significant advances in our understanding of this process of life's emergence will be made. Progress will mean coming to understand a variety of plausible chemical scenarios by which living systems might have emerged, but it is unrealistic to expect that the scenario that occurred some four billion years ago can be deduced as claimed by some critics (Meyer 2009). This suggests that all possible routes to life be explored and avoiding prejudice as to which processes had priority.

Thus we should not expect the scenario by which life originated, but rather a collection of scientifically feasible routes that can be fitted together into an ensemble of plausible scenarios. This parallels the understanding of paleontologists for whom the phenomenon to be explained is the overall pattern of transitional forms rather that the specific path of descent of some lineage (Miller 2003). This is also consistent with our developing understanding of how complex systems behave and what we can expect to be able to learn about them.

As pointed out by Ronald Fox, the hard problem for understanding the emergence of life is not so much how the necessary chemical components came into being but how it came to be that a digital type code in nucleic acids came to specify the analogical information of the protein catalysts that make the tens of thousands of reactions and signals of metabolism possible (Fox 1997; see also the extensive discussion in Hoffmeyer 2009). The emergence and increase of novel, specified, functional information remains the crucial issue (Krüppers 1990; Kauffman 1993, 2000, 2004; Depew and Weber 1995; Weber 1998; Meyer 2003, 2004, 2009; Bradley 2004; Yockey 2005; Deacon 2006). Another way to state this problem is how did the 'informed' organization of living systems come about? A promising new conceptual approach comes from the new sciences of emergent complexity.

\section{The Complex Systems View of the Emergence of Life}

In the past few decades, conceptual and computational developments have given rise to what may be characterized as the sciences of complexity, or complex systems dynamics. In this new field, non-linear dynamics, non-equilibrium thermodynamics, and information theory, inter alia have been joined to address the behavior of complex systems (Prigogine 1980, 1997; Peacocke 1983; Brooks and Wiley 1986: Wicken 1987; Pagels 1988; Swenson 1989; Waldrup 1992; Casti 1994; Weber and Depew 1996; Ulanowicz 1997, 2009; Bar-Yam 1997; Dewar 2003; Taylor 2003; 
Kleidon and Lorenz 2005; Schneider and Sagan 2005). Exploration of the dynamics of complex systems has reinvigorated notions of and interest in the process of emergence, which seems to be intimately connected with the self-organization observed in complex systems (Ulanowicz 1997; Kauffman 2000; Corning 2002, 2003; Morowitz 2002; Silberstein 2002; Deacon 2003, 2006; Clayton 2004, 2006; Schneider and Sagan 2005). Such systems have a type of natural teleology in the sense that there are rewards for competing entities that function to produce more thermodynamic or informational entropy externally while building internal structural and informational organization, or that decrease gradients of matter/energy more effectively (Weber and Depew 1996; Camazine et al. 2001).

Kauffman, who has applied such approaches to the origin of life, views the emergence of life as an expectable phenomenon, "We can think of the origin of life as an expected emergent collective property of a modestly complex mixture of catalytic polymers" (Kauffman 1993, xvi, emphasis in original). A ensemble of proto-cells could emerge even in the absence of genetic information, indeed that role of nucleic acids could have come later, with of course very great consequences for the stability of such systems over time. "If this model is correct," Kauffman writes, "then the routes to life in the universe are broader than imagined" Kauffman 1993, 330). Kauffman worries though if we understand enough about how natural systems self-organize, whether we have a viable theory of organization that allows not only for the emergence of complexity but agency (Kauffman 2000, 2004). Kauffman's project is to work toward an understanding of what he calls the "fourth law" of thermodynamics that can be used to explain and explore the wide range of phenomena that proceed spontaneously (under the right conditions) to greater complexity. Ian Stewart agrees that there is a lack of closure such that another principle is needed; he sees the quest for a fourth law having as its goal:

To formalize or explain the tendency of living systems to increase their order.

Any such law must be formulated in a context-dependent manner and not simply adjoined to the first three laws of thermodynamics on the assumption that such laws are universally valid. Kauffman's proposals about autonomous agents are suitably context dependent. (Stewart 2003, 141-142).

Kauffman assumes that the universe is not closed and fully determined by initial and boundary conditions, but that it is open and that the possibility space so enormous that 14 to 15 billion years has allowed for only a very small exploration of possible organization; of course this makes the formulation of the putative fourth law more problematic (Kauffman 2000). Such a putative law is envisioned as favoring the emergence of life, as described by autocatalytic cycles capable of reproduction, performing thermodynamic work cycles (extracting energy from gradients), and exhibiting autonomous agency (Morowitz 1992: Kaufmann 1993, 2000, 2004; Weber 1998; Ulanowicz 1997, 2002, 2004, 2009; Deacon 2006).

Terrence Deacon has addressed a broader issue of developing a theory of general biology by proposing that we expand our conception of organism to include a wider variety of organized systems (Deacon 2006 and forthcoming). He suggests a taxonomy of natural organization that distinguishes entities that are organized, selfmaintaining, self-reproducing chemical systems (designated 'Autaea' because of 
their autonomous self-maintenance) from all other configurations of matter. Autaea include living organisms, but also chemical systems that he calls 'autocells,' which exhibit coherent integrated organization and self-reproduction by direct morphological means, not via "coded" (e.g. genetic) mechanisms. Autocells are members of a taxon he calls 'Morphota' (characterized by morphological reproduction) that is distinguished from 'Semeota,' reproduction via separate transmission of genetic representation (Deacon forthcoming). Morphota exhibit properties that are intermediate between simple self-organization on the one hand and life on the other. Morphota have functions and thus exhibit a primitive form of "purpose" derived from the integration of their component self-organizing processes, but they are not alive in any usual sense. To the extent that self-organizational properties of the universe more generally are considered, the proper analog of a coherently integrated self-organizing universe would be to Morphota rather than Semoeta. This allows us to identify purpose of a kind in the universe irrespective of the distinctive characteristics of life. It also suggests that life did not arise as an event that transformed dead matter, but rather as a process of emergence from rich chemical dynamical systems. Deacon applies his notion of autocell dynamics specifically to the problem of the emergence of life in an attempt to delineate the logical requirements of the dynamics of life's emergence, regardless of the chemical specifics in any specific location or time (Deacon 2006). In his view, as that of Weber and Depew, natural selection emerges as a phenomenon with the emergence of life, in which it is an instance of a more general selective principle interacting with self-organizational principles (Weber and Depew 1996; Weber 1998, 2000; Weber and Deacon 2000; Deacon 2003, 2006).

While Peter Corning agrees that the crucial problem is understanding how emergent complexity comes about; he argues that a new law per se does not need to be discovered, but rather a recognition of a principle of synergy that encompasses chance, necessity, selection and teleonomy (appearance of goal-directed behavior that is actually because of the action of natural law), but which also gives a major role to history. For Corning, history matters, "Evolution is not simply an epiphenomenon of a few deep laws" (Corning 2003, 293). He sees that the science of history, which he hopes can be developed, is not dissimilar to the theory of organization to which Kauffman aspires, since, particularly in his more recent writings, Kauffman views the universe as having an almost unlimited number of potential states, of which only a miniscule fraction have been explored in the last 14 billion years or so, and hence its history, though contingent, is non-ergodic. Rather than being an enemy to the emergence of life and mind, Kauffman's exploration of possibility space provides the opportunity for these to emerge, in some sense, as an expectation of the action of natural processes. Arguing from different premises based upon observations of evolutionary convergence, Simon Conway Morris comes to a similar conclusion about the inevitability of life and mind within the limitations of life, as we know it on earth (Conway Morris 2003). Contingency is constrained by convergence.

Life may well be expected anywhere in the universe where the right type of conditions obtain, and those conditions may well be broader than those of terrestrial life. But, if history is important, then the particular trajectories of the emergence and evolution of life may not be so inevitable. The appearance of more complex 
cells and multi-cellular organisms may depend upon contingent events as much as the action of deep laws. If we should encounter living entities elsewhere we will likely recognize them as alive, but we might find alien minds, well, alien.

\section{Implications of Naturally Emergent Living Systems}

Shifting the discourse about chance, necessity, design (apparent or real), and teleology in nature from assumptions of a closed universe, in which initial and boundary conditions determine the future, to that of an open universe, in which genuine novelty can emerge, would constitute a paradigm shift in which there might be a "teleology without teleology" as Paul Davies suggested (Davies 1998). Philip Clayton similarly suggests that there can be a proto-purpose or "purposiveness without purpose" (Clayton 2004, 97, emphasis in original). Recent speculations point to such a possibility, that the universe is radically non-ergodic in principle and that genuine, unexpected novelty has and will continue to arise by the processes of nature (Kauffman 2000: Conway Morris 2003; Deacon 2003; Ulanowicz 2004; Weber and Depew 2004; Clayton 2004).

If such notions prove sustainable, there are important implications for science, for design arguments, and for teleology. As Charles Harper notes, "a scientific appraisal of the nature of reality admitting hierachically emergent ontology requires that theories of everything cannot aspire to completeness" (Harper 2005, 47). Paul Davies opines that:

emergent laws of complexity offer reasonable hope for a better understanding not only of biogenesis [ie emergence of life-, but of biological evolution too. Such laws might differ from the familiar laws of physics in a fundamental and important respect. Whereas the laws of physics merely shuffle information around, a complexity law might actually create information, or at least wrest it from the environment and etch it onto a material structure. (Davies 1999, 259, emphasis in original.)

A putative "fourth law" would thus be expected to not only have a role for history but also for information generation. Perhaps there is a new science of "infodynamics" coming into being. Robert Laughlin writes, "I think a good case can be made that science has now moved from an Age of Reductionism to an Age of Emergence, a time when the search for ultimate causes of things shifts from the behavior of parts to the behavior of the collective" (Laughlin 2005, 208). He notes, "Nature is regulated not only by a microscopic rule base but by powerful and general principles of organization. Some of these principles are known, but the vast majority are not" (Laughlin 2005, xi). Laughlin argues that informational organizational principles are prior to the laws of physics, "since principles of organization - or, more precisely, their consequences - can be laws, these can themselves organize into new laws, and these into still newer laws, and so on" (Laughlin 2005, 7).

Emphasis on emergence shifts attention from static structures, which might be construed as designed, to process in which both laws and chance play crucial roles. Earlier, Davies argued that the laws of nature allow for "genuine emergence 
of complexity in nature, an emergence that requires these laws but goes far beyond a mere unfolding of their consequences" (Davies 1998, 151). Thus complexity requires not just the action of laws but also radical chance to produce selforganization and emergence, such that the process is not simply deterministic. Because of the role of chance Davies doubts that the laws of physics can be said to contain life or mind. But the principles of emergence give rise to novelty just because history is important. Thus, the laws of physics are necessary, though not sufficient, for the emergence of life and mind. Emergent structures may give the appearance of well-crafted design, but "it is entirely the result of natural process. In effect, it renders a teleology without providing one" (Davies 1998, 151). This teleology without teleology is, I believe, a teleology of emergent organization and complexity. As I argue (Weber 2009), this is not the teleology of the classical design arguments of Plato, Cicero, William Paley or William Prout, but rather more like the teleology of Aristotle, Kant, Asa Gray or Charles Darwin, in which causality and purpose exists within organisms or in their relationship to the environment. Nor is it even the teleology of William Whewell, with his emphasis on the properties of deep laws. Rather, in such a natural teleology, chance is not the enemy but a collaborator in creation. Embracing emergent complexity as a phenomenon, caused by laws very deep in the grain of nature, opens new avenues for scientific and philosophical thought. As Paul Davies notes, “...it is clear that any general principle of advancing complexity would reintroduce a teleological element into science" (Davies 2004, 207).

\section{Taking the Biosemiotic Turn}

Viewing causality, purpose, function, and "meaning" of living systems in both their internal organization and their relationship to their environments implies a semiotic view (Barbieri 2003, 2008; Hoffmeyer 2009). In addressing the problem of the emergence of such systems, not only are accounts of the putative production of the molecular building blocks needed, but how they come to be organized through processes of emergence and to exhibit the range of phenomena associated with such systems, including self-description, epigenesis, natural selection, increase of semiotic freedom, and semiotic survival. For biosemiotic phenomena to emerge, Hoffmeyer suggests five necessary conditions that need to be met (Hoffmeyer 2009). There must be autocatalytic closure, of the kind Kauffman suggests provides selfsufficiency, and secondly physical, osmotic closure provided by membranes or membrane-like structures that not only define self and not-self but also allow lifesustaining transport, chemiosmotic coupling, and semiotic processes. A crucial step involves a self-referential, digital re-description in DNA and RNA of the analog structure/function of proteins sustaining metabolic transformations and energy transducing processes.Further, extended autocatalysis emerges involving information and sign processing for prokaryotes or the internal processing in eukaryotes with their internal membranous structures. Finally, membranes become interfaces or other-reference systems serving to integrate self-reference and other reference. This biosemiotic perspective is richer than a replicator/interactor model and shifts attention to the full range of phenomena exhibited by living systems. It fits 
perspicuously with the approach of seeking to understand the origin of such systems as processes of emergent complexity. As we develop the sciences of complex systems dynamics and apply them to the problem of the origin of life, biosemiotics will have an important role to play in formulating research problems and working to develop a theory of general biology. Taking the biosemiotic turn focuses attention not just on the crucial role of membranes and the emergence of the digital code of nucleic acids, but also how information transducing mechanisms, signaling, and interpretation, as well as agency, emerged with the appearance of living systems.

Acknowledgements An earlier version of this paper was published in Zygon 42:837-856 (2007).

\section{References}

Arrhenius, G., Sales, B., Mojzsis, S., \& Lee, T. (1997). Entropy and charge in molecular evolution-the case of phosphate. Journal of Theoretical Biology, 187, 503-522.

Bachman, P. A., Luisi, P. L., \& Lang, J. (1992). Autocatalytic self-replication micelles as modes for prebiotic structures. Science, 357, 57-58.

Bada, J. L. (2004). How life began on earth: a status report. Earth and Planetary Science Letters, 226, 1-15.

Bada, J. L., \& Lazcano, A. (2003). Prebiotic soup-revisiting the Miller experiment. Science, 300, $745-746$.

Baltscheffsky, M. \& Baltscheffsky, H. (1992). Inorganic pyrophosphate and inorganic pyrophosphatases. Molecular Mechanisms in Bioenergetics, 331-348.

Bar-Yam, Y. (1997). Dynamics of complex systems. Reading: Perseus.

Barbieri, M. (2003). The organic codes: An introduction to semiotic biology. Cambridge: Cambridge University Press.

Barbieri, M. (ed). (2008). Introduction to biosemiotics: The new biological synthesis. Dordrecht: Springer. Behe, M. J. (1996). Darwin's black box: The biochemical challenge to evolution. New York: The Free.

Benner, S. A., Ricardo, A., \& Carrigan, M. A. (2004). Is there a common chemical model for life in the universe? Current Opinion in Chemical Biology, 8, 672-689.

Bernal, J. D. (1951). The physical basis of life. London: Routledge \& Kegan Paul.

Bernal, J. D. (1967). The origin of life. Cleveland: World.

Bradley, W. L. (2004). Information, entropy, and the origin of life. In W. A. Dembski \& M. Ruse (Eds.), Debating design: From Darwin to DNA. Cambridge: Cambridge University Press.

Brooks, D. R., \& Wiley, E. O. (1986). Evolution as entropy: Toward a unified theory of biology. Chicago: University of Chicago Press.

Camazine, S., Deneubourg, J.-L., Franks, N. R., Sneyd, J., Theraulaz, G., \& Bonabeau, E. (2001). Selforganization in biological systems. Princeton: Princeton University Press.

Carter, C. W., \& Kraut, J. (1974). A proposed model for interaction of polypeptides with RNA. Proceedings of the National Academy of Science USA, 71, 283-287.

Casti, J. L. (1994). Complexification: Explaining a paradoxical world through the science of surprise. New York: Collins.

Cech, T. R. (1986). Bootstrapping model of the origin of life. BioSystems, 15, 209-219.

Cech, T. R. (1987). The chemistry of self-splicing RNA and RNA enzymes. Science, 236, 4360-4363.

Clayton, P. (2004). Mind \& Emergence: From quantum to consciousness. Oxford: Oxford University Press.

Clayton, P. (2006). Biology, directionality, and God: Getting clear on the stakes for religion-science discussion. Theology and Science, 4, 121-127.

Conway Morris, S. (2003). Life's solutions: Inevitable humans in a lonely universe. Cambridge: Cambridge University Press.

Corning, P. A. (2002). The re-emergence of "emergence": a venerable concept in search of a theory. Complexity, 7(6), 18-30.

Corning, P. A. (2003). Nature's magic: Synergy in evolution and the fate of humankind. Cambridge: Cambridge University Press. 
Darwin, C. (1859). On the origin of species by means of natural selection, or the preservation of favoured races in the struggle for life. London: John Murray. available also as a facsimile reprint (1964), with an introduction by Ernst Mayr, Cambridge, MA: Harvard University Press.

Davies, P. (1998). Teleology without teleology: Purpose through emergent complexity. In R. J. Russell, W. R. Stoeger \& F. J. Ayala (Eds.), Evolutionary and molecular biology: Scientific perspectives on divine action (pp. 151-162). Vatican City: Vatican Observatory.

Davies, P. (1999). The fifth miracle: The search for the origin and meaning of life. New York: Simon \& Schuster.

Davies, P. (2004). Emergent complexity, teleology, and the arrow of time. In W. A. Dembski \& M. Ruse (Eds.), Debating design: From Darwin to DNA (pp. 191-209). Cambridge: Cambridge University Press.

Dawkins, R. (1976). The selfish gene. Oxford: Oxford University Press.

Dawkins, R. (1989). The selfish gene: New edition. Oxford: Oxford University Press.

Deacon, T. W. (2003). The hierarchic logic of emergence: untangling the interdependence of evolution and self-organization. In B. H. Weber \& D. J. Depew (Eds.), Evolution and learning: The Baldwin effect reconsidered (pp. 273-308). Cambridge: MIT.

Deacon, T. W. (2006). Reciprocal linkage between self-organizing processes is sufficient for selfreproduction and evolvability. Biological Theory, 1(2), 1-14.

Deamer, D. W. (1992). Polycyclic aromatic hydrocarbons: Primitive pigment systems in the prebiotic environment. Advances in Space Research, 12, 1-4.

Deamer, D. W., \& Pashley, R. M. (1989). Amphiphilic components of the Murchison carbonaceious chondrite: Surface properties and membrane formation. Origin of Life and Evolution of the Biosphere, 19, 21-38.

Deamer, D. W., Dworkin, J. P., Sandford, S. A., Bernstein, M. P., \& Allamandola, L. J. (2002). The first cell membranes. Astrobiology, 2, 371-381.

Dembski, W. A. (1998). The design inference: Eliminating chance through small probabilities. Cambridge: Cambridge University Press.

Depew, D. J., \& Weber, B. H. (1995). Darwinism evolving: Systems dynamics and the genealogy of natural selection. Cambridge: MIT.

Desmond, A. (1989). The politics of evolution. Chicago: Chicago University Press.

Dewar, R. (2003). Information theory explanation of the fluctuation theorem, maximum entropy production and self-organized criticality in non-equilibrium stationary states. Journal of Physics A: Mathematical and General, 36, 631-641.

Fox, S. W. (1965). Simulated natural experiments in spontaneous organization of morphological units from proteins. In S. W. Fox (Ed.), The origins of prebiological systems and their molecular matrices (pp. 361-382). New York: Academic Press.

Fox, R. F. (1982). Biological energy transduction: The Oroboros. New York: Wiley.

Fox, R. F. (1988). Energy and the evolution of life. New York: Freeman.

Fox, R. F. (1997). The origins of life: What one needs to know. Zygon, 32, 393-406.

Fry, I. (2000). The emergence of life on earth: A historical and scientific overview. New Brunswick: Rutgers University Press.

Gesteland, R. F., \& Atkins, J. F. (1993). The RNA world: The nature of modern RNA suggests a prebiotic RNA world. Cold Spring Harbor: Cold Spring Harbor.

Haldane, J. B. S. (1929). The origin of life. In J. D. Bernal (Ed.), Rationalist animal, reprinted in The origin of life (pp. 242-249). Cleveland: World.

Harper, C. L., Jr. (2005). What does a slug know about Mozart? Introducing the ontological multiverse. In C. L. Harper Jr. (Ed.), Spiritual information. Philadelphia and London: Templeton Foundation.

Hoffmeyer, J. (2009). Biosemiotics: An examination into the signs of life and the life of signs. Scranton: University of Scranton Press.

Imai, E., et al. (1999). Elongation of oligopeptides in a simulated submarine hydrothermal system. Science, 283, 831-833.

Joyce, G. F., \& Orgel, L. E. (1993). Prospects for understanding the origin of the RNA world. In R. F. Gesteland \& J. F. Atkins (Eds.), The RNA World (pp. 1-25). Cold Spring Harbor: Cold Spring Harbor.

Kauffman, S. A. (1993). The origins of order: Self-organization and selection in evolution. New York: Oxford University Press.

Kauffman, S. A. (2000). Investigations. New York: Oxford University Press.

Kauffman, S. A. (2004). Autonomous agents. In J. D. Barrow, P. C. W. Davies \& C. L. Harper Jr. (Eds.), Science and ultimate reality: Quantum theory, cosmology and complexity. Philadelphia and London: Templeton Foundation. 
Kleidon, A., \& Lorenz, R. D. (2005). Non-equilibrium thermodynamics and the production of entropy: Life, earth, and beyond. Heidelberg: Springer Verlag.

Krüppers, B.-O. (1990). Information and the origin of life. Cambridge MA: MIT Press.

Kumar, J. K., \& Oliver, J. S. (2002). Proximity effects in monolayer films: Kinetic analysis of amide bond formation in the air-water interface using proton NMR spectroscopy. Journal of the American Chemical Society, 124, 11307-11314.

Lahav, N. (1999). Biogenesis: Theories of life's origin. New York: Oxford University Press.

Lal, A. K. (2008). Origin of life. Astrophysics Space Science, 317, 267-278.

Lane, N. (2006). Power, sex, suicide: Mitochondria and the meaning of life. Oxford: Oxford University Press.

Laughlin, R. B. (2005). A different universe: Reinventing physics from the bottom down. New York: Basic Books.

Leman, L., Orgel, L., \& Ghadiri, M. R. (2004). Carbonylsulfide-mediated prebiotic formation of peptides. Science, 306, 283-286.

Liebman, S. A., Pesce-Rodriguez, R. A., \& Matthews, C. N. (1995). Organic analysis of hydrogen cyanide polymers: Prebiotic and extraterrestrial chemistry. Advances in Space Research, 15(3), 71-80.

Luisi, P. I. (2006). The emergence of life: From chemical origins to synthetic biology. Cambridge: Cambridge University Press.

Lurquin, P. F. (2003). The origins of life and the universe. New York: Columbia University Press.

Martin, W., \& Russell, M. T. (2003). On the origin of cells: A hypothesis for evolutionary transitions from abiotic geochemistry to chemoautotropic prokaryotes, and from prokaryotes to nucleated cells. Philosophical Transactions of the Royal Society of London (Series B), 358, 59-85.

Matthews, C. N., \& Moser, R. E. (1967). Peptide synthesis from hydrogen cyanide and water. Nature, 215 , 1230-1234.

Meyer, S. C. (2003). DNA and the origin of life: Information, specification, and explanation. In J. H. Campbell \& S. C. Meyer (Eds.), Darwinism, design, and public education (pp. 223-285). Lansing: Michigan State University Press.

Meyer, S. C. (2004). The origin of biological information and the higher taxonomic categories. Proceedings of the Biological Society of Washington, 117(2), 213-239.

Meyer, S. C. (2009). Signature in the Cell: DNA and the Evidence for Intelligent Design. New York: Harper One.

Miller, S. L. (1953). A production of amino acids under possible primitive earth conditions. Science, 117, 528-529.

Miller, K. B. (2003). Common descent, transitional forms, and the fossil record, in Perspectives on an Evolving Creation (pp. 152-181). Grand Rapids: Eerdmans.

Minard, R. D., Hatcher, P. G., Gourley, R. C., \& Matthews, C. N. (1998). Structural investigations of hydrogen cyanide polymers: new insights using TMAH thermochemolysis/GC-MS. Origins of Life and Evolution of the Biosphere, 28, 461-473.

Mitchell, P. D. (1961). Coupling of phosphorylation to electron and hydrogen transfer by a chemiosmotic type of mechanism. Nature, 191, 144-148.

Morowitz, H. J. (1992). Beginnings of cellular life: Metabolism recapitulates biogenesis. New Haven: Yale University Press.

Morowitz, H. J. (2002). The emergence of everything: How the world became complex. New York: Oxford University Press.

Morowitz, H., Deamer, D. W., \& Smith, T. (1991). Biogeneisis as an evolutionary process. Journal of Molecular Evolution, 33, 207-208.

Oparin, A. I. (1924). Proiskhozhdenie zhizy. Moscow: Moskovski Rabochii.

Oparin, A. I. (1938). The origin of life. London: Macmillan.

Orgel, L. E. (1968). Evolution of the genetic apparatus. Journal of Molecular Biology, 38, 381-393.

Orgel, L. W. (1992). Molecular replication. Nature, 358, 203-209.

Oró, J. (1961). Mechanism of synthesis of adenine from hydrogen cyanice under possible primitive earth conditions. Nature, 191, 1193-1194.

Ourisson, G., \& Nakatani, Y. (1994). The terpenoid theory of the origin of cellular life: the evolution of terpenoics do cholesterol. Current Biology, 1, 11-23.

Pagels, H. R. (1988). The dreams of reason: The computer and the rise of the sciences of complexity. New York: Simon and Schuster.

Peacocke, A. R. (1983). An introduction to the physical chemistry of biological organization. Oxford: Oxford University Press.

Powner, M. W., Gerland, B., \& Sutherland, J. D. (2009). Synthesis of activated pyrimidine ribonucleotides in prebiotically plausible conditions. Nature, 459, 239-242. 
Prebble, J., \& Weber, B. H. (2003). Wandering in the gardens of the mind: Peter Mitchell and the making of Glynn. New York: Oxford University Press.

Prigogine, I. (1962). Introduction to non-equilibrium thermodynamics. New York: Wiley Interscience.

Prigogine, I. (1980). From being to becoming: Time and complexity in the physical sciences. New York: Freeman.

Prigogine, I. (1997). The end of certainty: Time, chaos, and the new laws of nature. New York: The Free.

Prigogine, I., \& Stengers, I. (1984). Order out of chaos: Man's new dialogue with nature. New York: Bantam.

Royce, J. (1904). Herbert Spencer: An estimate and review. New York: Collier.

Ruse, M. (2006). Darwinism and its discontents. New York: Cambridge University Press.

Schneider, E., \& Sagan, D. (2005). Into the cool: Energy flow, thermodynamics, and life. Chicago: University of Chicago Press.

Schopf, J. W. (1983). Earth's earliest biosphere: Its origin and evolution. Princeton: Princeton University Press.

Schwartz, A. W. (1997). Speculation on the RNA precursor problem. Journal of Theoretical Biology, 187, 523-527.

Scott, E. C. (2004). Evolution vs. creationism: An introduction. Westport: Greenwood.

Silberstein, M. (2002). Reduction, emergence and explanation. In P. Machamer \& M. Silberstein (Eds.), The Blackwell guide to the philosophy of science (pp. 80-107). Malden: Blackwell.

Spencer, H. (1864). The principles of biology. London: Williams and Norgate.

Stewart, I. (2003). The second law of gravitics and the fourth law of thermodynamics. In N. H. Gregerson (Ed.), From complexity to life: On the emergence of life and meaning. Cambridge MA: Harvard University Press.

Strick, J. E. (2000). Sparks of life: Darwinism and the Victorian debates over spontaneous generation. Cambridge: Harvard University Press.

Swenson, R. (1989). Emergent attractors and the law of maximum entropy production: foundations to a theory of general evolution. Systems Research, 6, 187-197.

Szostak, J. W. (2009). Systems chemistry on early earth. Nature, 459, 171-172.

Taylor, M. C. (2003). The moment of complexity: Emerging network cultures. Chicago: University of Chicago Press.

Ulanowicz, R. E. (1997). Ecology the ascendant perspective. New York: Columbia University Press.

Ulanowicz, R. E. (2002). Ecology, a dialog between the quick and the dead. Emergence, 4(1), 34-52.

Ulanowicz, R. E. (2004). Ecosystem dynamics: a natural middle. Theology and Science, 2(2), 231-253.

Ulanowicz, R. E. (2009). A third window: Natural life beyond Newton and Darwin. West Conshohochen: Templeton Foundation.

Wächterhäuser, G. (1988a). Before enzymes and templates: theory of Surface Metabolism. Microbiological Reviews, 52, 452-484.

Wächterhäuser, G. (1988b). Pyrite formation, the first energy source for life: a hypothesis. Systematic and Applied Microbiology, 10, 207-210.

Wächterhäuser, G. (1992). Groundworks for an evolutioinary biochemistry: the iron-sulfur world. Progress in Biophysics and Molecular Biology, 58, 85-201.

Wächterhäuser, G. (1997). The origin of life and its methodological challenge. Journal of Theoretical Biology, 187, 483-494.

Waldrup, M. M. (1992). Complexity: The emerging science at the edge of order and chaos. New York: Simon and Schuster.

Watson, J. D., \& Crick, F. C. (1953). Molecular structure of nucleic acids: a structure for deoxyribose nucleic acid. Nature, 171, 737-738.

Weber, B. H. (1998). Emergence of life and biological selection from the perspective of complex systems dynamics. In G. Van de Vijver, S. N. Salthe \& M. Delpos (Eds.), Evolutionary systems: Biological and epistemological perspectives on selection and self-organization (pp. 59-66). Kluwer: Dordrecht.

Weber, B. H. (2000). Closure in the emergence and evolution of life. Annals of the New York Academy of Sciences, 901, 132-138.

Weber, B. H. (2007). Emergence of life. Zygon, 42, 837-856.

Weber, B. H. (2009). Design and its discontents. Synthese (in press).

Weber, B. H., \& Depew, D. J. (1996). Natural selection and self-organization: dynamical models as clues to a new evolutionary synthesis. Biology and Philosophy, 11, 33-65. 
Weber, B. H., \& Deacon, T. (2000). Thermodynamic cycles, developmental systems, and emergence. Cybernetics and Human Knowing, 7, 21-43.

Weber, B. H., \& Depew, D. J. (2004). Darwinism, design and complex systems dynamics. In W. A. Dembski \& M. Ruse (Eds.), Debating design: From Darwin to DNA (pp. 173-190). Cambridge: Cambridge University Press.

Weber, B. H., \& Prebble, J. N. (2006). An issue of originality and priority: The correspondence and theories of oxidative phosphorylation of Peter Mitchell and Robert J.P. Williams, 1961-1980. Journal of the History of Biology, 39, 125-163.

Westheimer, F. H. (1987). Why nature chose phosphates. Science, 235, 1173-1178.

Wicken, J. S. (1987). Evolution, information and thermodynamics: Extending the Darwinian program. New York: Oxford University Press.

Williams, R. J. P. (1961). Possible functions of chains of catalysts. Journal of Theoretical Biology, 1, $1-17$.

Williams, R. J. P., \& Fraústo da Silva, J. R. R. (1996). The natural selection of the elements. Oxford: Oxford University Press.

Williams, R. J. P., \& Fraústo da Silva, J. R. R. (1999). Bringing chemistry to life: From matter to man. Oxford: Oxford University Press.

Williams, R. J. P., \& Frausto da Silva, J. R. R. (2003). Evolution was chemically constrained. Journal of Theoretical Biology, 220, 323-343.

Williams, R. J. P., \& Frausto da Silva, J. R. R. (2006). The chemistry of evolution. Amsterdam: Elsevier.

Williams, R. J. P., \& Frausto, J. R. R. (2008). Evolution revisited by inorganic chemists. In J. D. Barrow, S. Conway Morris, S. J. Freeland \& C. L. Harper Jr. (Eds.), Fitness of the cosmos for life: Biochemistry and fine-tuning (pp. 456-489). Cambridge: Cambridge University Press.

Wills, C., \& Bada, J. (2000). The spark of life: Darwin and the primeval soup. Cambridge: Perseus.

Wilson, T. J., \& Lilley, D. M. (2009). The evolution of ribozyme chemistry. Science, 323, 1436-1438.

Wilson, C., \& Szostak, J. W. (1995). In vitro evolution of a self-replicating ribozyme. Nature, 374, $777-782$.

Woese, C. (1967). The evolution of the genetic code. In The genetic code (pp. 179-195). New York: Harper \& Row.

Yamagata, Y., \& Inomata, K. (1997). Condensation of glycylglycine to oligoclycines with trimetaphosphate in aqueous solution. Origins of Life and Evolution of the Biosphere, 27, 339-344.

Yockey, H. P. (2005). Information theory, evolution, and the origin of life. Cambridge: Cambridge University Press. 